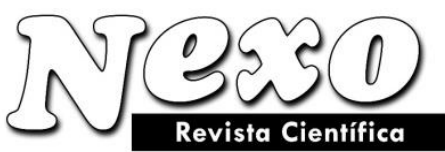

Vol. 34, No. 01, pp. 477-488/Marzo 2021

\title{
Transformation of the reproduction of human capital in the context of the digital economy
}

\section{Transformación de la reproducción del capital humano en el contexto de la economía digital}

\author{
Elena Anatolievna Stryabkova*, Julia Vladimirovna Lyshchikova, Natalya Anatolievna \\ Gerasimova, Anna Mihailovna Kulik, Elena Vladimirovna Weis \\ Belgorod State University, Belgorod, Russia. \\ *stryabkova@bsu.edu.ru
}

(recibido/received: 05-December-2020; aceptado/accepted: 27-February-2021)

\begin{abstract}
The relevance of the study is determined by the fact that the processes of reproduction of human capital with the most recent quality characteristics, skills, and competencies are actively evolving in the context of the digital transformation of the economy. The goal of the article is to study transformation processes and to identify the main characteristics of the reproduction of human capital in the context of digital and technological transformation. The empirical base of the study is represented by the data from the Federal State Statistics Service of the Russian Federation, as well as from reports and statistical books of the National Research University Higher School of Economics on the development of human capital and digital economy in Russia. The methodological basis of the study includes a systemic and holistic approach, retrospective, evolutionary, monographic, and comparative logical analysis, content analysis of scientific literature and empirical sources, as well as methods of generalization and systematization. The stages of the evolution of human capital have been identified and described in the course of the study; a model of the evolution of the human capital structure in the digital economy has been formed, including its traditional and new characteristics; the physical, intellectual, socioindustrial, and digital (technological) components of the reproduction of human capital in the Russian Federation and the Central Federal District have been analyzed. The conclusion has been drawn of the need to transform the mechanisms of the reproduction of human capital for the formation of new digital and technological competencies and for overcoming the divergence of technogenesis and anthropogenesis.
\end{abstract}

Keywords: human capital, digital transformation, convergence of technologies, reproduction processes, evolution model.

\section{RESUMEN}

La relevancia del estudio está determinada por el hecho de que los procesos de reproducción del capital humano con las características de calidad, habilidades y competencias más recientes están evolucionando activamente en el contexto de la transformación digital de la economía. El objetivo del artículo es estudiar los procesos de transformación e identificar las principales características de la reproducción del capital humano en el contexto de la transformación digital y tecnológica. La base empírica del estudio está 
representada por los datos del Servicio de Estadísticas del Estado Federal de la Federación de Rusia, así como por los informes y libros estadísticos de la Escuela Superior de Economía de la Universidad Nacional de Investigación sobre el desarrollo del capital humano y la economía digital en Rusia. . La base metodológica del estudio incluye un enfoque sistémico y holístico, análisis retrospectivo, evolutivo, monográfico y lógico comparativo, análisis de contenido de la literatura científica y fuentes empíricas, así como métodos de generalización y sistematización. Las etapas de la evolución del capital humano se han identificado y descrito en el curso del estudio; se ha formado un modelo de evolución de la estructura del capital humano en la economía digital, incluyendo sus características tradicionales y nuevas; Se han analizado los componentes físicos, intelectuales, socioindustriales y digitales (tecnológicos) de la reproducción del capital humano en la Federación de Rusia y el Distrito Federal Central. Se ha llegado a la conclusión de la necesidad de transformar los mecanismos de reproducción del capital humano para la formación de nuevas competencias digitales y tecnológicas y para superar la divergencia de la tecnogénesis y la antropogénesis.

Palabras clave: capital humano, transformación digital, convergencia de tecnologías, procesos de reproducción, modelo de evolución.

\section{INTRODUCTION}

The modern trends in technological transition and digitalization of society increase the importance of such components of the country's national wealth as human capital. The relevance of issues related to transformation of the reproduction of human capital is growing in the context of digitalization, when economic relations are actively evolving, and the vector of their development is directed towards the intangible areas such as the knowledge economy, advanced production technologies, and NBICS convergence, for example.

The following foreign researchers considering the essence and formation of human capital made a significant contribution to the development of this area: J. Mincer (1958) identified the main characteristics of the "human capital" concept; G. Becker (1962) formulated the theory of investment in an individual as a carrier of human capital; Th. Schultz (1961) defined human capital as a source of income, the formation of which depended on the abilities and skills of the individual and the level of education; and G. Psacharopoulos (1981) formed a model of investment in human capital, where he estimated the costs associated with education.

The following Russian researchers deal with the development of human capital: S. A. Dyatlov (1994) described human capital using a combination of certain factors (knowledge, skills, health, etc.); R. I. Kapelyushnikov (1993) formulated the concept of human capital as a certain stock of skills, abilities, and motivations of an individual, as well as the level of their knowledge embodied in themselves; and L. G. Simkina (2002) considered the relationship between human capital and the innovation economy.

The development of human capital in new transformational conditions is analyzed in the works of such authors as P. Romer (1990), who analyzed technological changes, human capital, and endogenous economic growth; George Messinis (Messinis, Ahmed, 2008), who described the impact of technology diffusion on human capital; L. E. Basovskiy (2015), who evaluated the impact of advanced technologies and human capital on the formation of new technological orders; and L.E. Grinin (2015), who determined the impact of the sixth technological cycle and the cybernetic revolution on the development of human capital in his work.

As such, human capital is actively evolving, transforming, becoming more complex, and acquiring a completely new format at the moment. Digital transformations result in the need to acquire digital 
knowledge and competencies by carriers of human capital, while the processes of reproduction of human capital at all levels are changing, which requires a comprehensive study.

\section{MATERIALS AND METHODS}

The empirical basis of the study was represented by the data of the Federal State Statistics Service of the Russian Federation (Regiony Rossii, 2020), the report of the National Research University Higher School of Economics with the contribution of the World Bank "Growth Scenarios for the Russian Economy Taking into Account the Contribution of Human Capital" (Akindinova, Yasin, Avdeeva, 2019), the report of the Center for Labor Research and the Laboratory for Labor Market Research of the National Research University Higher School of Economics "Russian Labor Market: Trends, Institutions, Structural Changes" (Gimpelson, Kapelyushnikov, Roshchin, 2017), and the statistical book of the National Research University Higher School of Economics "Indicators of Digital Economy" (Indikatory tsifrovoy ekonomiki, 2020).

General scientific dialectical and quantitative research methods, including analysis, synthesis, systemic and holistic approach, retrospective, evolutionary, monographic, comparative logical analysis, content analysis of scientific literature and empirical sources, as well as methods of generalization and systematization were used as a methodological basis for the study.

\section{RESULTS}

The authors identified four main stages in the interpretation and characteristics of this scientific category when considering the evolution of human capital. For example, the first stage refers to $1960-1975$, when the founders of the term "human capital" proposed an interpretation of this scientific category (Becker, 1962; Schultz, 1961), based on the knowledge gained in the learning process. Subsequently, the structure of human capital included such components as investment and professional mobility at the second stage of the evolution of this concept (Blaug, 1994; Psacharopoulos, 1981).

At the third stage, the researchers focused on the fact that human capital was the source of the competitive advantage of territories (Leonidova et al., 2013). The structure of human capital becomes more complicated with the development of new technologies under the coherent and integration impact of transformational processes; the set of its main parameters implemented in the digital economy changes (Borshch, Zharova, 2019; Kolmykova, Zelenov, 2020). The authors agree that human capital is being formed in a new format at the moment (it is going through the fourth stage of its development), enriched with new elements, and acquiring additional properties of digital competence.

A general view of the human capital evolution scheme with due consideration of digital transformations is shown in Figure 1. 


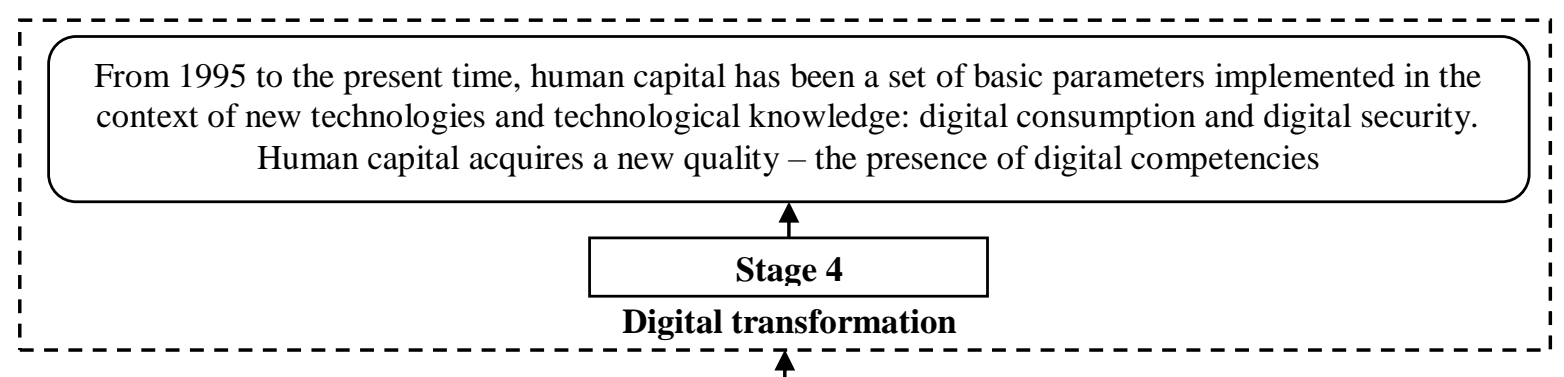

From 1990 to 1994, human capital was a source of competitive advantage of territories, a set of qualities that determined labor productivity that brought a certain income

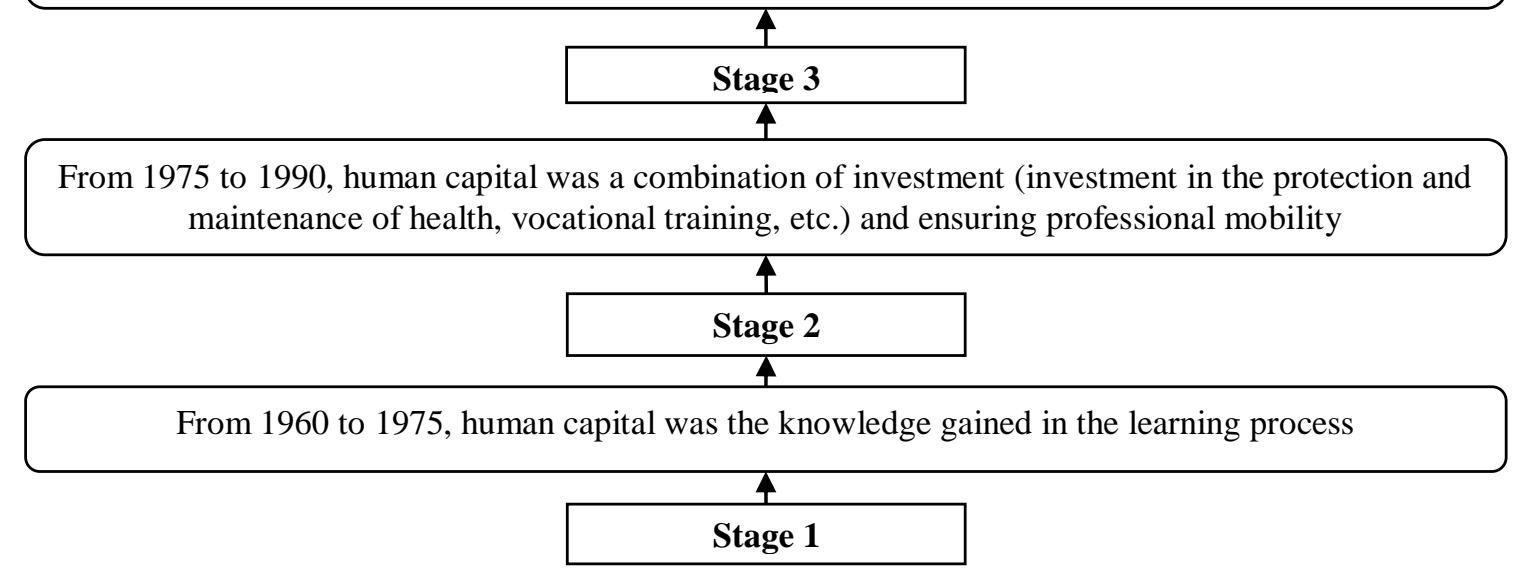

Figure 1. Human capital evolution scheme with due consideration of digital transformations

The evolution model of the economic structure of human capital, which includes its main features, should include both its traditional dominant characteristics, such as heredity, continuity, variability, transfer, selection, and new ones that appear in the digital economy: intellectualization, creativity, virtualization, and commercialization, the formation of which is influenced by the digital environment. These elements are associated with the impact of digital transformation and relate to the physical health of the bearer of human capital, influence the increase in their intelligence, and create conditions that motivate the individual to acquire new skills and competencies (cognitive, sociobehavioral, and digital skills). A new element of human capital is emerging in the digital economy - the integration of the carrier of human capital with end-to-end digital technologies (Figure 2). 


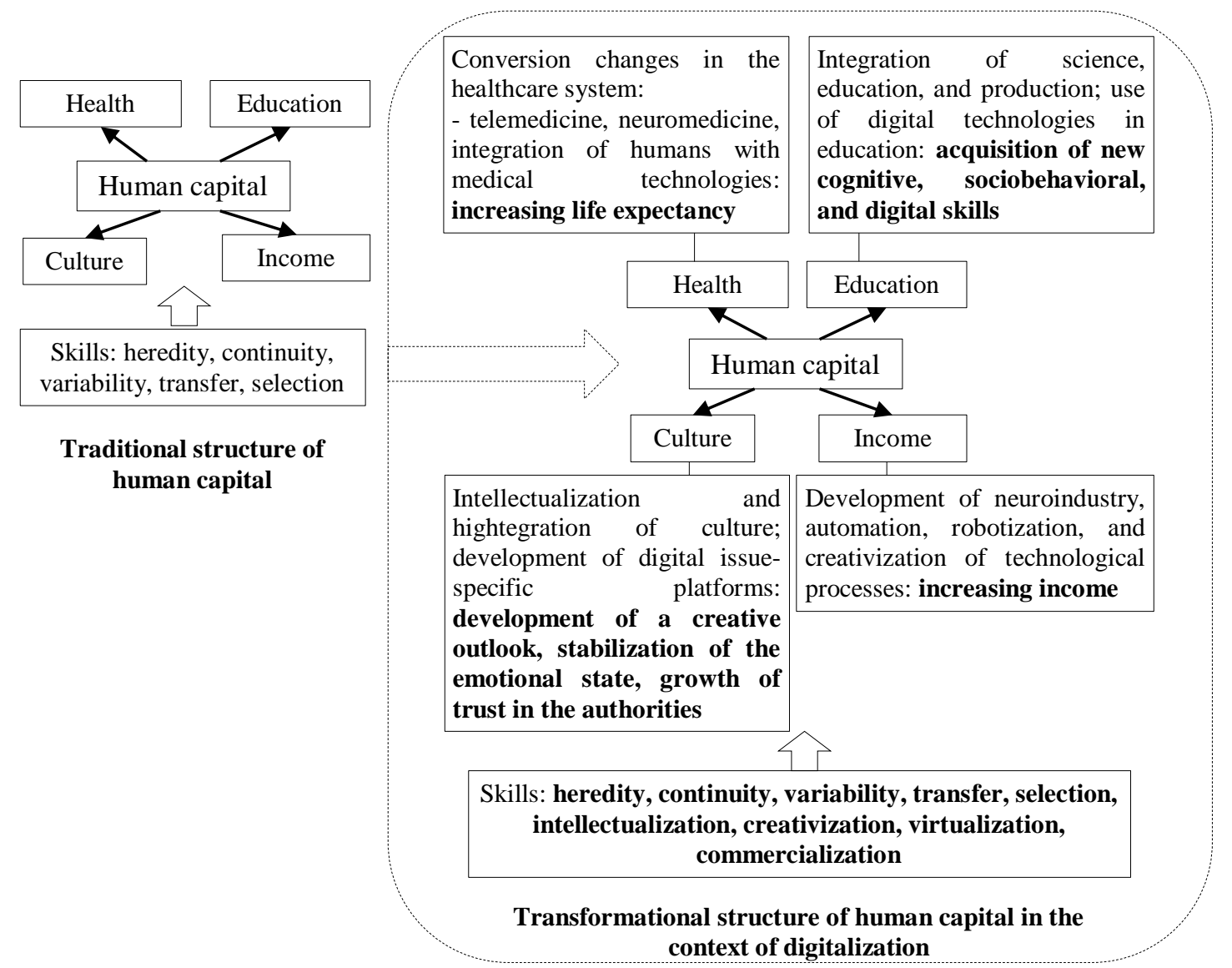

Figure 2. Main transformational characteristics of the evolution model of the human capital structure in the context of the digital economy

Focusing on the reproduction of human capital, it must be noted that a human is the main productive force and the creator of material and spiritual resources of the society transforming in the digital economy, and therefore, the reproduction of human capital during digital transformations is one of the most important factors that directly influence the dynamics of socioeconomic development. Simple reproduction of human capital is understood as the process of recreating and maintaining human capital in an unchanged form, both quantitatively and qualitatively (Zagurskaya, 2020). The reproduction of human capital can be influenced by such determinants as the potential level of knowledge, human performance, their position in society, climate of their family, human health, their financial and social capital, environmental conditions of their existence, institutional environment, and their entrepreneurial abilities.

There is an opinion (Avdeev, Ternovykh, 2020) that the process of reproduction of human capital must be considered from two standpoints: the quantitative and qualitative renewal of human capital within the framework of the existing type of production relations. The authors note that the reproduction of human capital is associated with the renewal of relations headed by the individual bearer of human capital and its owner (enterprise, industry, or state).

Traditional methodological approaches to assessing the level of reproduction of human capital provide for the disclosure of its functional characteristics through the use of such qualitative indicators as the level of education and qualifications of workers, conditions for maintaining the health of individuals, increase in public spending on the formation of abilities in the creative area and the entrepreneurial area, level of knowledge accumulation, etc. 
Considering different standpoints regarding the assessment of the reproduction of human capital, the authors emphasize the work (Gogitidze, 2011) that proposes to assess it from the perspective of three groups of indicators: education capital, healthcare and sociocultural development indicators, and indicators of the intellectual component of the scientific knowledge. However, in the opinion of the authors, the listed set of indicators should be supplemented with a group of indicators reflecting the impact of digitalization on the reproduction of human capital. Indeed, as the authors rightly point out, human capital is an important determinant of the development of the modern transformational society along with the ICT infrastructure and the economic environment (Kolmykova, Zelenov, 2020).

The authors believe that the following components of the reproduction of human capital must be assessed in order to estimate the reproduction of human capital in the context of digital transformations:

1. Physical component of the reproduction of human capital (indicators of health and healthcare, which are the basis of the reproductive potential of the population);

2. Intellectual component of the reproduction of human capital (main parameters of knowledge, skills, abilities, and conditions allowing to increase the intellectual level of the individual);

3. Social and production component of the reproduction of human capital (level of social security and well-being of the working-age population); and

4. Digital (technological) component of the reproduction of human capital (parameters and opportunities for the population in the region to acquire the basic competencies necessary for successful functioning in the context of digital and technological transformation).

A sample of the main indicators of the reproduction of human capital in the Russian Federation and the Central Federal District (CFD) is presented in Table 1.

Table 1. Sample of the main indicators of the reproduction of human capital in the Russian Federation and the CFD

\begin{tabular}{|c|c|c|c|c|c|}
\hline \multirow{2}{*}{ Indicator } & \multicolumn{5}{|l|}{ Year } \\
\hline & 2014 & 2015 & 2016 & 2017 & 2018 \\
\hline \multicolumn{6}{|c|}{ Physical component of the reproduction of human capital } \\
\hline \multicolumn{6}{|c|}{ Morbidity rate per 1,000 people } \\
\hline Russian Federation & 787.1 & 778.2 & 785.3 & 778.9 & 782.1 \\
\hline CFD & 715.0 & 698.9 & 704.0 & 695.1 & 703.3 \\
\hline \multicolumn{6}{|c|}{ Level of investment in healthcare, mln rub. } \\
\hline Russian Federation & $195,384.8$ & $188,136.5$ & $181,786.0$ & $176,805.0$ & $201,071.5$ \\
\hline CFD & $37,755.4$ & $51,407.9$ & $53,655.9$ & $59,779.7$ & $53,505.9$ \\
\hline \multicolumn{6}{|c|}{ Migration rate of population growth per 10,000 people } \\
\hline Russian Federation & 19 & 17 & 18 & 14 & 9 \\
\hline CFD & 49 & 38 & 46 & 18 & 27 \\
\hline \multicolumn{6}{|c|}{ Intellectual component of the reproduction of human capital } \\
\hline \multicolumn{6}{|c|}{ Investment in education, mln rub. } \\
\hline Russian Federation & $236,361.8$ & $239,789.8$ & $210,626.7$ & $221,153.2$ & $267,856.7$ \\
\hline CFD & $58,353.7$ & $57,795.4$ & $55,002.7$ & $58,129.4$ & $58,798.1$ \\
\hline \multicolumn{6}{|c|}{ Number of organizations providing educational services in the field of higher education and scientific organization } \\
\hline Russian Federation & 950 & 896 & 818 & 766 & 741 \\
\hline CFD & 371 & 342 & 306 & 280 & 266 \\
\hline \multicolumn{6}{|c|}{ Social and production component of the reproduction of human capital } \\
\hline \multicolumn{6}{|c|}{ Average annual number of the employed, thous. people } \\
\hline Russian Federation & $72,080.6$ & $72,424.9$ & $72,065.2$ & $71,842.7$ & $71,561.7$ \\
\hline CFD & $21,390.2$ & $21,178.0$ & $21,181.9$ & $21,259.7$ & $21,198.5$ \\
\hline
\end{tabular}




\begin{tabular}{|c|c|c|c|c|c|}
\hline \multicolumn{6}{|c|}{ Income of the population, $\%$ of the previous year } \\
\hline Russian Federation & 99.2 & 96.4 & 95.5 & 99.8 & 101.1 \\
\hline CFD & 96.3 & 96.2 & 96.5 & 103 & 101 \\
\hline \multicolumn{6}{|c|}{ Investment in public administration and military security; social security, mln rub. } \\
\hline Russian Federation & $236,010.7$ & $240,061.8$ & $278,854.9$ & $277,921.4$ & $256,904.5$ \\
\hline CFD & $53,477.2$ & $45,528.2$ & $51,949.3$ & $48,486.5$ & $69,071.5$ \\
\hline \multicolumn{6}{|c|}{ Digital (technological) component of the reproduction of human capital } \\
\hline \multicolumn{6}{|c|}{ Investment in informatization and communications activities, mln rub. } \\
\hline Russian Federation & $353,982.8$ & $367,754.5$ & $384,224.8$ & $429,771.6$ & $557,144.1$ \\
\hline CFD & $113,746.7$ & $139,004.8$ & $161,915.2$ & $209,706.9$ & $314,697.6$ \\
\hline \multicolumn{6}{|c|}{ Share of the population using the Internet for ordering goods and/or services, $\%$ of the total } \\
\hline Russian Federation & 17.8 & 19.6 & 23.1 & 29.1 & 34.7 \\
\hline CFD & 20.3 & 23.6 & 25.6 & 33.5 & 40.1 \\
\hline \multicolumn{6}{|c|}{ Use of the Internet by the population, $\%$ of the total } \\
\hline Russian Federation & 74.1 & 77.7 & 80.8 & 83.7 & 87.3 \\
\hline CFD & 75.6 & 79.9 & 82.2 & 86.2 & 88.9 \\
\hline \multicolumn{6}{|c|}{$\begin{array}{l}\text { Indicator of the use of information technologies and information telecommunication networks in households, } \% \\
\text { the total number of households (personal computer) }\end{array}$} \\
\hline Russian Federation & 71.0 & 72.5 & 74.3 & 74.4 & 72.4 \\
\hline CFD & 73.4 & 74.9 & 77.5 & 78.0 & 76.8 \\
\hline
\end{tabular}

The analysis of the data presented in the table allows to conclude that the morbidity rate is decreasing both in the Russian Federation and in the regions. It must be noted that there is an increase in investment in the healthcare system both in the Russian Federation as a whole and in the CFD in particular, which undoubtedly improves the quality of medical care for the population. The quality of medical care to the population also depends on the use of digital services of the Unified State Healthcare Information System. The authors note that the level of digitalization of medical institutions in the Russian Federation has a positive trend, which can be seen in Figure 3.

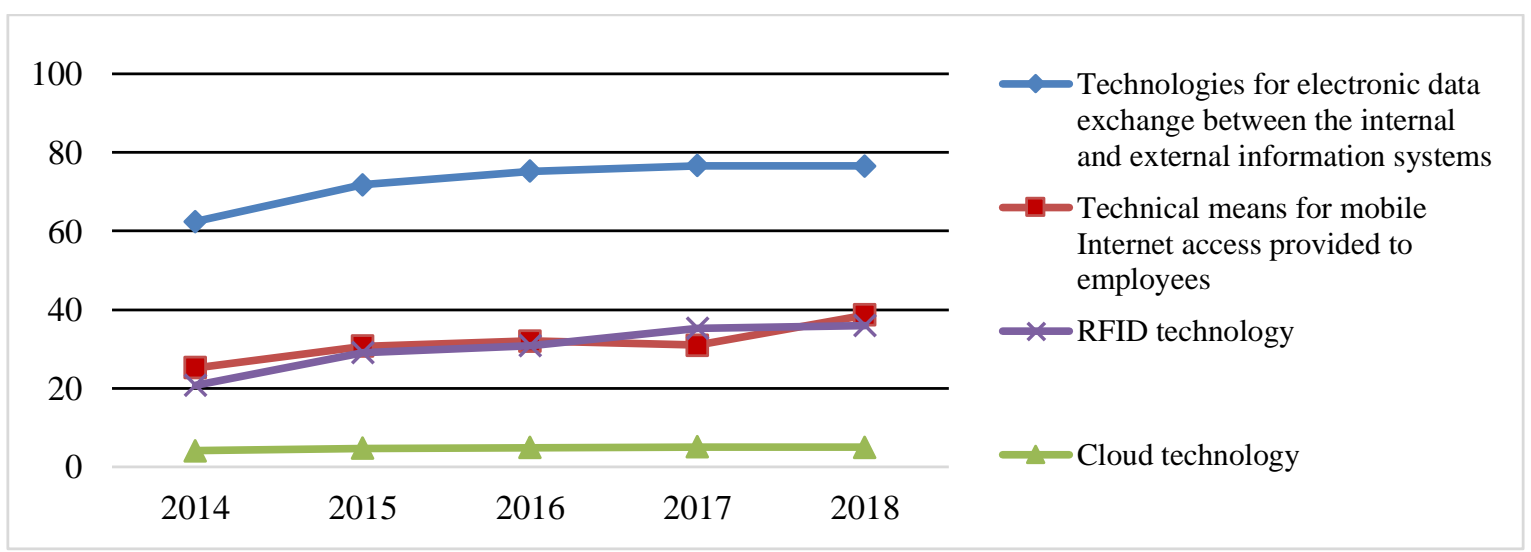

Figure 3. Digitalization of medical institutions in the Russian Federation in 2015 - 2018

(\% of the total number of medical institutions)

It can be noted when assessing the intellectual component of the reproduction of human capital that the indicator of the dynamics of investment in education has a positive trend. For example, there is an increase in investment in education by $13.3 \%$ in the Russian Federation and by $0.24 \%$ in the CFD. However, there is a decrease in the number of educational institutions, both in the Russian Federation as a whole and in the CFD in particular, which undoubtedly plays a rather negative role for the intellectual component of the reproduction of human capital. Educational institutions of higher education and scientific organizations are the main organizational form of ensuring the integration of education, research, and development with 
the real sector of the economy, which allows for the formation and reproduction of basic digital and technological competencies.

Digitalization has a positive effect on the dynamics of employment in information and communications: the number of the employed in information and communications in the Russian Federation increased by $20.4 \%$ during the analyzed period. There is also an increase in the internal costs of organizations for the creation, distribution, and use of digital technologies by sectors of the economy (Figure 4), with the largest share of the costs borne by organizations in the business sector.

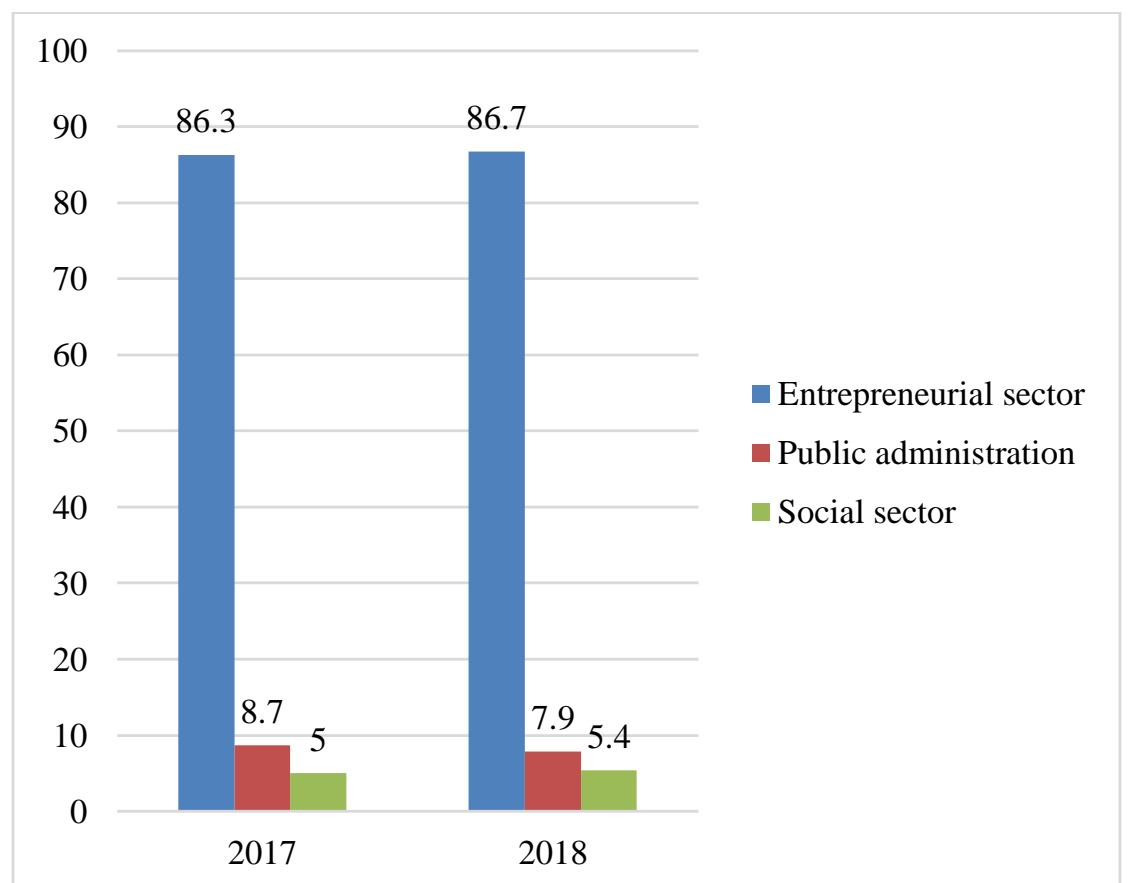

Figure 4. Structure of the internal costs of organizations for the creation, distribution, and use of digital technologies and related products and services by sectors in the Russian Federation, \%

The structure of the entrepreneurial sector in terms of the level of implementation of digital technologies is described by the business digitalization index, which determines the level of use of the broadband Internet, cloud services, RFID technology, ERP systems, and the involvement of entrepreneurial sector organizations in e-commerce. This index has a fairly high value in 2018, and the highest indicators are typical for such activities as telecommunications, wholesale and retail trade, information technology industry, and the processing industry (Figure 5). 


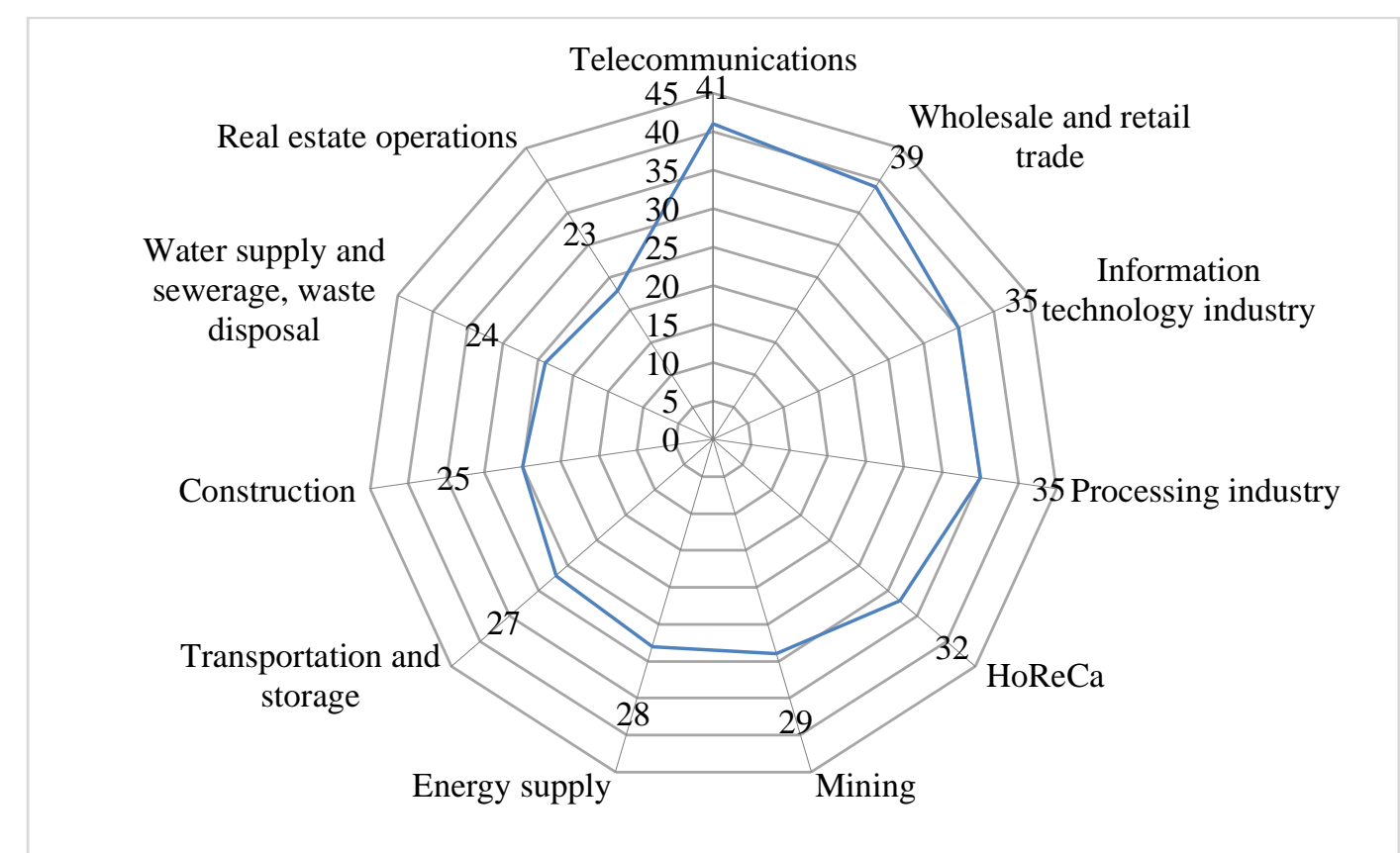

Figure 5. Index of business digitalization in the Russian Federation by types of economic activity in 2018

It must be noted when analyzing the digital component of the reproduction of human capital that investment in informatization and communications activities are growing at a fairly high pace. For example, the volume of investment increased by $57.3 \%$ in the Russian Federation and by $176.6 \%$ in the CFD in 2018, compared to 2014. The share of online sales is also growing: by $16.9 \%$ in the Russian Federation and by $19.8 \%$ in the CFD during the analyzed period. There is an increase in the share of population using information and telecommunication technologies.

\section{DISCUSSION}

New technological factors influence the reproduction of human capital in the context of digital transformation. They endow carriers of human capital with new skills and competencies, thereby increasing its quality.

The main determinants can be identified among the factors of changing the structure of human capital, such as conversion changes in the healthcare system; processes of integrating science and education with production using digital technologies; development of neuroindustry, automation, and robotization; creativization of technological processes; digitalization of living conditions; revalorization of the authorities' transparency due to the possibility of digital monitoring of their activities; development of digital platforms for culture, healthcare, etc. The importance of the latest digital and technological competencies for the performance of work functions and integration with the social sector is increasing. These skills will come to the fore and become vital for people in the context of digital transformation. The level of their possession will determine the success of the life of the bearer of human capital and the prospects for their employment.

In the newest context of the transformational influence of the digital economy on human capital, the risk of a technological singularity increases in particular, which manifests itself as a divergence of technogenesis and anthropogenesis. The digital economy involves the integration of a set of digital technologies with a human. Exponential technological growth, or technogenesis, will be fairly natural in such context, and technogenesis will significantly outstrip the stages of human capital development (anthropogenesis), i.e., there will be a divergence of human capital and technological growth in this 
context. This divergence can be overcome only with the intensive development of the intellectual form of the reproduction of human capital.

This determines the need to intensify transformations associated with the possibility of acquiring new digital and technological skills and competencies by the population: reforming the education system and increasing research and development costs in the main priority areas related to digitalization. These are fairly important measures that will lead to overcoming the divergence of human capital and technological growth.

\section{CONCLUSIONS}

Summarizing the above, it can be concluded that digital transformation and convergent development of technologies cause a new round in the evolution of human capital and change its qualitative and quantitative characteristics. In the opinion of the authors, the greatest technological breakthrough and the development of digital technologies will occur where effective conditions are created for the development and reproduction of human capital. Moreover, human capital should be considered through the view of the main parameters implemented in the context of new technologies, technological knowledge, digital consumption, and digital security. Integration with digital technologies and new qualitative characteristics, such as basic digital literacy, data analytics capabilities, machine learning ability, ability to work in combination with artificial intelligence, etc., are becoming inherent in human capital.

The divergence of human capital can be overcome and technological growth is possible only with the intensive development of the intellectual form of the reproduction of human capital. The bearers of human capital do not yet fully possess digital literacy skills and lack a set of necessary competencies. This is also related to the problems of the existing traditional education system, which does not yet fully take into consideration the fact that changes in the modern conditions are taking place both in the system of the human's motivation for learning and education and in the system of labor organization. A high-quality and systemic transformation of the intellectual component of human capital is required, because the need for high-quality human capital, which has all the necessary technological competencies to exist in digital realities, does not yet find sufficient satisfaction both in the regions of the Russian Federation and in the country as a whole.

\section{ACKNOWLEDGEMENTS}

The study was carried out as part of the state assignment FZWG-2020-0016 (0624-2020-0016), the topic of the project "Fundamental foundations of global territorial and industry specialization in the context of digitalization and technology convergence".

\section{REFERENCES}

Akindinova, N.V., Yasin, E.G., Avdeeva, D.A. (2019). Stsenarii rosta rossiyskoy ekonomiki s uchetom vklada chelovecheskogo kapitala [Scenarios of growth of the Russian economy taking into account the contribution of human capital]: report for the XX International Scientific Conference on the Problems of Economic and Social Development, Moscow, April 9 - 12, 2019. Moscow: Publishing House of the Higher School of Economics.

Avdeev, E.V., Ternovykh, K.S. (2020). Vosproizvodstvo obshchestvennogo chelovecheskogo kapitala [Reproduction of social human capital]. Moscow Economic Journal, 5, 844 - 852. 
Basovskiy, L. E. 2017. Otsenka vliyaniya novykh tekhnologiy i chelovecheskogo kapitala na formirovaniye novykh ukladov v ekonomike Rossii [Assessment of the impact of new technologies and human capital on the formation of new structures in the Russian economy]. Economics, 5(1), $18-21$.

Becker, G.S. (1962). Investment in Human Capital: A. Theoretical Analysis. Journal of Political Economy, Supplement, Oct, 9 - 49.

Blaug, M. (1994). Economic Theory in Retrospect. Moscow: Delo.

Borshch, L.M., Zharova, A.R. (2019). Metodologiya razvitiya chelovecheskogo kapitala s pozitsiy tsifrovoy ekonomiki [Methodology for the development of human capital from the standpoint of the digital economy]. Creative economics, 13(11), 2,141-2,158.

Dyatlov, S.A. (1994). Osnovy teorii chelovecheskogo kapitala [Foundations of the theory of human capital]. Saint Petersburg: Saint Petersburg University of Economics and Finance.

Gimpelson, V., Kapelyushnikov, R., Roshchin, S. (2017). Rossiyskiy rynok truda: tendentsii, instituty, strukturnyye izmeneniya [Russian labor market: trends, institutions, structural changes]. Report of the Center for Labor Research and the Laboratory for Labor Market Research. Moscow: NRU HSE. Retrieved from: https://www.hse.ru/mirror/pubs/share/218427624

Gogitidze, M.V. (2011). Otsenka urovnya vosproizvodstva chelovecheskogo kapitala makroregiona [Assessment of the level of reproduction of human capital in the microregion]. Bulletin of the DSTU, 11(3(54)), $401-407$.

Grinin, L.E., Korotaev, A.V. (2015). Globalnoye stareniye naseleniya, shestoy tekhnologicheskiy tsikl i kiberneticheskaya revolyutsiya. Kondratyevskiye volny: naslediye i sovremennost [Global population aging, the sixth technological cycle and the cybernetic revolution. Kondratieff waves: heritage and modernity]. Volgograd: Teacher, 7, $107-132$.

Indikatory tsifrovoy ekonomiki [Indicators of the digital economy]: statistical book. (2020). Moscow: NRU HSE.

Kapelyushnikov, R.I. (1993). Chelovecheskiy kapital Rossii: problemy reabilitatsii [Human capital of Russia: problems of rehabilitation]. Society and Economics, 9(10), $4-13$.

Kolmykova, T.S., Zelenov, A.V. (2020). Novoye kachestvo chelovecheskogo kapitala v kontekste tsifrovoy transformatsii ekonomicheskogo prostranstva [New quality of human capital in the context of digital transformation of the economic space]. Economics and Management: Problems, Solutions, 1(4), 4 -8 .

Leonidova, G.V., Ustinova, K.A, Popov, A.V., Panov, A M., Golovchin, M.A., Solovieva, T.S., Chekmareva, E.A. (2013). Problemy effektivnosti gosudarstvennogo upravleniya. Chelovecheskiy kapital territoriy: problemy formirovaniya i ispolzovaniya [Problems of the efficiency of public administration. Human capital of territories: problems of formation and use]: monograph. Vologda: Institute of SocioEconomic Development of Territories of the Russian Academy of Sciences.

Messinis, G., Ahmed, A.D. (2008). Valuable Skills. Human Capital and Technology Diffusion: Working Paper, 38, 34. 
Mincer, J. (1958). Investment in Human Capital and Personal Income Distribution. Journal of Political Economy, 66(4), $281-302$.

Psacharopoulos, G. (1981). Returns to Education: An Updated International Comparison. Comparative Education, 17(3), $321-341$.

Regiony Rossii [Regions of Russia]. (2020). Socioeconomic indicators. Statistical book of Rosstat. Retrieved from: https://rosstat.gov.ru/folder/210/document/13204

Romer, P. (1990). Endogenous Technological Change. Journal of Political Economy, 98(5), 71 - 102.

Schultz, Th.W. (1961). Investment in Human Capital. The American Economic Review, 51(1), 1 - 17.

Simkina, L.G. (2002). Chelovecheskiy kapital v innovatsionnoy ekonomike [Human capital in an innovative economy]. Saint Petersburg: Saint Petersburg State University of Economics.

Zagurskaya, T.N. (2020). Faktory vosproizvodstva chelovecheskogo kapitala v sisteme upravleniya innovatsionnym razvitiyem regiona [Factors of reproduction of human capital in the system of management of innovation-driven growth of the region]. Proceedings of the XXI National Scientific Conference (with international participation) "Modernization of Russian society and education: new economic guidelines, management strategies, issues of law enforcement and personnel training." April 2020. Taganrog: Publishing house of the TMEI. 